\title{
KAJIAN TENTANG KARAKTER BERBASIS NILAI-NILAI KEARIFAN LOKAL PADA MASYARAKAT ADAT KAMPUNG KUTA KECAMATAN TAMBAKSARI KABUPATEN CIAMIS
}

\author{
Trisna Sukmayadi \\ Prodi PPKn FKIP Universitas Ahmad Dahlan \\ email: trisnasukmayadi@ppkn.uad.ac.id
}

\begin{abstract}
This study was aimed at exploring the values of local wisdom of the indigenous peoples whose existence is still kept below the brunt of globalization and modernization so strong. This is a case study. Its results indicate: (1) the indigenous peoples perceived that local knowledge is a cultural heritage as a noble value, handed down by ancestors as identity formation and identity that must be maintained and preserved. Characters that are inherited are soft, regular, efficiency, discipline, shared caring, teach each other, sincere, obedient I submissive, visionary (thinking ahead), responsible, dedicated, loyal, sympathy, empathy, compassion, tolerance sense, willing to sacrifice, faith and piety, simple, cherish health, thoughtful, and constructive thinking, which are reflected in the art, proverbs, and way of life; (2) the inheritance of the character value is done by oral traditions and examples directly transmitted through traditional ceremonies; (3) The persistence reinforcing factor of the values of local wisdom, is the fact that "pamali" (meaning prohobition), is still held firmly by community.
\end{abstract}

Keywords: Local wisdom, character values, customs

\section{PENDAHULUAN}

Kebudayaan merupakan identitas suatu bangsa yang dapat membedakan bangsa tersebut dengan bangsa lainnya. Undang-Undang Dasar 1945 Pasal 32 mengamanatkan bahwa negara memajukan kebudayaan nasional Indonesia di tengah peradaban dunia dengan menjamin kebebasan masyarakat dalam memelihara dan mengembangkan nilai-nilai budayanya. Dalam konteks ini, pemerintah menjamin kebebasan masyarakat dalam memelihara dan mengembangkan nilai-nilai budaya yang tumbuh dan berkembang di masyarakat Indonesia. Pada era globalisasi, pemerintah berkewajiban melindungi dan melayani masyarakat dalam memelihara dan mengembangkan nilai-nilai budayanya agar tidak tergerus oleh nilai-nilai budaya global yang tidak sesuai dengan karakter dan jati diri bangsa.

Dewasa ini ada enam permasalahan yang dihadapi bangsa Indonesia dalam pembangunan karakter bangsa, yaitu: disorientasi dan belum dihayatinya nilai- 
nilai Pancasila sebagai filosofi dan ideologi bangsa; keterbatasan perangkat kebijakan terpadu dalam mewujudkan nilai-nilai esensi Pancasila; bergesernya nilai-nilai etika dalam kehidupan bermasyarakat, berbangsa, dan bernegara; memudarnya kesadaran terhadap nilai-nilai budaya bangsa; ancaman disintegrasi bangsa; dan melemahnya kemandirian bangsa (Sukadi, 2011: 81).

Persoalan budaya dan karakter bangsa kini menjadi sorotan tajam masyarakat. Sorotan itu mengenai berbagai aspek kehidupan, tertuang dalam berbagai tulisan di media cetak, wawancara, dialog, dan gelar wicara di media elektronik. Selain di media massa, para pemuka masyarakat, para ahli, para pengamat pendidikan, dan pengamat sosial berbicara mengenai persoalan budaya dan karakter bangsa di berbagai forum seminar, baik pada tingkat lokal, nasional, maupun internasional. Persoalan yang muncul di masyarakat seperti korupsi, kekerasan, kejahatan seksual, perusakan, perkelahian massa, kehidupan ekonomi yang konsumtif, kehidupn politik yang tidak produktif, dan sebagainya menjadi topik pembahasan hangat di media massa, seminar, dan di berbagai kesempatan. Berbagai alternatif penyelesaian diajukan seperti peraturan, undang-undang, peningkatan upaya pelaksanaan dan penerapan hukum yang lebih kuat. Publikasi Pusat Kurikulum Badan Penelitian dan Pengembangan Kementerian Pendidikan Nasional (2010: 1).

Cogan (Aryani, 2010:38) berpendapat bahwa sebagai warga negara yang baik/warga negara seutuhnya memiliki sejumlah ciri utama, yaitu (1) rasa kepribadian/jati diri mandiri (a sense of identity), baik sebagai insan ilahiah, sosial, maupun kebangsaan. Ciri mandiri ini dapat dilihat dari bergbagai dimensi (geografis, etnis, dan agama), serta mampu menuju kehidupan yang globalistik. (2) rasa nikmat akan sejumlah haknya baik legal, political dan sosio-economical rights, serta mampu menjalankan secara baik dan benar. (3) rasa tanggung jawab akan kewajiban-kewajiban (obligation) yang menjadi keharusannya, sehingga selalu menjaga keseimbangan antara kepentingan public dengan privat, serta menjelmakan tanggung jawab (responsibility) menjadi kewajiban (obligation) dan tugas keharusan (duties). (4) minat dan keterlibatan akan public affairs (kepentingan umum) sehingga sikap, mau, dan mampu berpartisipasi secara aktif, krestif, positif/konstruktif, dan demokratis. (5) kemampuan untuk menyerap/ 
menerima nilai-nilai dasar kemasyarakatan (basic societal values); sehingga mampu menjalin dan membina kerjasama, kejujuran, kedamaian, serta rasa cinta dan kebersaan dalam mempersiapkan hari esok (futuristic orientation).

Pendidikan karakter yang harus dikembangkan di sekolah adalah nilai-nilai agama dan nilai-nilai budaya bangsa (kearifan lokal). Muatan materi yang diajarkan dalam pendidikan karakter tidak terlepas dari kearifan lokal yang dijadikan pegangan oleh masyarakatnya. Kearifan lokal yang ada dalam masyarakat merupakan salah satu muatan materi yang harus terkandung dalam pendidikan karakter. Nilai-nilai budaya masyarakat lain atau bangsa lain dapat diadopsi sejauh tidak bertentangan dan dapat mengembangkan nilai-nilai budaya luhur sendiri. Pemahaman ini sebenarnya tidak terlepas dari konsep dasar yang menyatakan bahwa pendidikan itu merupakan proses pewarisan nilai-nilai budaya suatu masyarakat kepada generasi berikutnya, sehingga pendidikan itu tidak dapat dilepaskan dari kebudayaan masyarakatnya.

Pendidikan karakter di lingkungan masyarakat, salah satunya adalah di masyarakat adat Kampung Kuta, yang berjalan mengikuti tahapan dan menjadi bagian dari proses dan tahapan kehidupan masyarakatnya. Sehingga nilai-nilai karakter yang menjadi keyakinan masyarakatnya dan yang harus secara terusmenerus diwariskan kepada generasi anak-anak mereka dapat diselenggarakan dengan mulus dan berhasil. Hal ini terbukti dengan bertahannya nilai-nilai karakter tersebut pada generasi sekarang sebagai generasi masyarakat penerusnya.

Keadaan tersebut diatas tidak terlepas dari adat dan budaya sunda. Setidaknya ada empat gaya hidup yang perlu dicermati dalam kebudayaan Sunda yang ada di Kabupaten Ciamis, yaitu kemampuan beradaptasi, kemampuan mobilitas, kemampuan tumbuh dan berkembang, serta kemampuan regenerasi.

Kampung Kuta terletak di Kecamatan Tambaksari, Kabupaten Ciamis. Kampung adat ini dihuni masyarakat yang hidup dilandasi kearifan lokal. Dengan memegang teguh budaya, pelestarian lingkungan di kampung ini bisa menjadi contoh bagi kita semua untuk tetap menjaga kelestarian lingkungan dengan berpegang teguh kepada budaya lokal. 
Kampung Kuta merupakan kampung adat, hal ini berdasarkan bahwa di kampung tersebut mempunyai kesamaan dalam bentuk dan bahan fisik bangunan rumah, adanya ketua adat, dan adanya adat istiadat yang mengikat masyarakatnya.

Masyarakat Kampung Kuta mempunyai keyakinan bahwa jika hal tersebut dilanggar, maka musibah atau marabahaya akan datang ke Kampung Kuta. Norma adat dan agama memiliki intensitas dan "kekuatan" yang seimbang sebagai pedoman dalam melangsungkan kehidupan secara keseluruhan.

Bila dilihat dari aspek pendidikan kaitannya dengan kearifan lokal, nilainilai budaya tersebut sudah sepantasnya menjadi bahan kajian yang mendalam guna memberikan warna dalam pengajaran, beberapa ahli mengatakan bahwa praktek pendidikan yang demikian itu adalah termasuk kepada praktek pendidikan yang mengutamakan etnopedagogi.

Berkaitan dengan hal di atas, Alwasilah (2006) mengatakan bahwa etnopedagogi memandang pengetahuan atau kearifan lokal (local knowledge, local wisdom) sebagai sumber inovasi dan keterampilan yang dapat diberdayakan demi kesejahteraan masyarakat. Kearifan lokal adalah koleksi fakta, konsep, kepercayaan, dan persepsi masyarakat ihwal dunia sekitar. Ini mencakup cara mengamati dan mengukur alam sekitar, menyelesaikan masalah, dan memvalidasi informasi. Singkatnya, kearifan lokal adalah proses bagaimana pengetahuan dihasilkan, disimpan, diterapkan, dikelola, dan diwariskan.

Berdasarkan latar belakang di atas, maka masalah yang akan dikaji adalah nilai-nilai kearifan lokal yang dibelajarkan masyarakat adat Kampung Kuta kepada generasi selanjutnya melalui pranata sosial yang membelajarkan nilai-nilai karakter kepada masyarakat dan faktor-faktor yang menjadi penguat bertahannya nilai-nilai kearifan lokal pada masyarakat adat Kampung Kuta di era globalisasi dan modernisasi.

\section{METODOLOGI PENELITIAN}

\section{Pendekatan Penelitian}

Penelitian ini menggunakan pendekatan kualitatif yang didasarkan pada dua alasan. Pertama, permasalahan yang dikaji dalam penelitian ini adalah penguatan pendidikan karakter berbasis nilai-nilai kearifan lokal pada masyarakat adat Kampung Kuta yang membutuhkan sejumlah data lapangan yang sifatnya 
aktual dan kontekstual. Kedua, pemilihan pendekatan ini didasarkan pada keterkaitan masalah yang dikaji dengan sejumlah data primer dari subjek penelitian yang tidak dapat dipisahkan dari latar alamiahnya. Hal ini sesuai dengan yang dikemukakan Nasution (2003: 5) menyatakan bahwa hakikat penelitian kualitatif adalah untuk mengamati orang dalam lingkunan hidupnya, berinteraksi dengan mereka, berusaha memahami bahasa dan tafsiran mereka tentang dunia sekitarnya. Permasalahan dalam penelitian ini bersumber pada interaksi manusia dalam hal kaitannya dengan nilai-nilai kearifan lokal yang sudah ada pada masyarakat adat Kampung Kuta sejak jaman dahulu, dan masih dipertahankan sampai saat ini.

Metode yang digunakan dalam penelitian ini adalah studi kasus. Pemilihan metode studi kasus karena metode ini dilakukan secara instensif, terperinci dan mendalam terhadap imdividu, kelompok, organisasi atau gejala tertentu. Adapun gejala tertentu yang khas dalam penelitian ini adalah bahwa masyarakat adat Kampung Kuta merupakan salah satu masyarakat adat yang memiliki komitmen dalam menjaga dan melestarikan nilai-nilai kearifan lokal.

Instrumen utama dalam penelitian ini adalah peneliti sendiri yang terjun ke lapangan untuk mencari informasi melalui observasi dan wawancara. Di dalam penelitian ini peneliti menggunakan pendekatan antar manusia, artinya selama proses penelitian peneliti akan lebih banyak mengadakan kontak dengan orangorang di sekitar lokasi penelitian yaitu masyarakat adat Kampung Kuta. Dengan demikian peneliti lebih leluasa mencari informasi dan data yang terperinci tentang berbagai hal yang diperlukan untuk kepentingan penelitian.

\section{HASIL PENELITIAN DAN PEMBAHASAN}

1. Nilai-Nilai Kearifan Lokal yang Dibelajarkan Masyarakat Adat Kampung Kuta Kepada Generasi Selanjutnya

\section{a. Persepsi Masyarakat Adat Kampug Kuta Terhadap Kearifan Lokal}

Warsim (51), Warja, dan Sanmarno (66), menuturkan bahwa keariafan lokal merupakan warisan budaya bangsa (amanat leluhur/karuhun), yaitu wujud dari adat istiadat dan perilaku sehari-hari yang dibentuk dengan jangka waktu sekian lama, dan diwariskan oleh leluhur/karuhun sehingga membentuk nilai-nilai adat dan tradisi yang khas. Warisan leluhur tersebut merupakan mata rantai yang tidak 
terputus. Oleh karena itulah kearifan lokal wajib untuk dijaga dan dilestarikan sebagai wahana pembentukan identitas dan jati diri.

Hal ini sejalan dengan apa yang dijelaskan oleh Lubis. N.H dalam Yayasan Kebudayaan Rancage (2001: 79) yang menjelaskan bahwa

kearifan tradisional adalah sesuatu yang berakar pada masa lalu dalam kehidupan tradisional lokal, yang dijadikan rujukan bagi tatanan kehidupan dan kebudayaan lokal masing-masing. Kearifan tradisional ini dapat disebut juga sebagai kearifan lokal. Setiap kelompok masyarakat memiliki kearifan tersendiri untuk memelihara kesatuan atau integritas dan juga jati diri kelompok atau kaumnya. Kearifan tradisional artinya wawasan atau cara pandang menyeluruh yang bersumber dari tradisi kehidupan. Karena tradisi itu adalah bagian dari kebudayaan, kearifan tradisional dapat berbeda antara satu kelompok dengan kelompok yang lain.

Seperti halnya pandangan di atas, kearifan lokal terbentuk dengan waktu yang sangat lama, bahkan sulit untuk diukur berapa lamanya. Hal-hal yang dihasilkan dalam konteks kearifan lokal pada masyarakat adat bersifat permanen. Artinya pada zaman manapun harus relevan dengan kondisi yang ada, dan masyarakat adat menyesuikan dengan kearifan lokal tersebut yang telah dibangun sepanjang masa.

Sesuai dengan pendapat narasumber, sebenarnya penjagaan dan pelesatrian kearifan lokal sangatlah penting. Oleh karena ini merupakan pengemasan tentang identitas dan jati diri suatu bangsa. Kearifan lokal dapat memperkukuh eksistensi jati diri bangsa yang nantinya akan membedakan antra bangsa yang satu dengan bangsa yang lain. Perbedan inilah yang dinamakan "khas" atau "kekhasan". Dengan kekhasan ini maka konstruk budayanya pun berbeda.

Alwasilah (2006: 18-20) juga menegaskan bahwa

....perlu adanya revitalisasi kebudayaan, yang oleh beliau didefinisikan sebagai upaya yang terencana, sinambung, dan diniati agar nilai-nilai budaya itu bukan hanya dipahami para pemiliknya tetapi malah membangkitkan segala wujud kreativitas dalam keseharian dan dalam menghadapi tantangan. Demi revitalisasi, maka ayat-ayat kebudayaan perlu dikaji ulang dan diberi tafsir baru. Tafsir baru akan mencerahkan manakala ada kaji banding secara kritis dengan berbagai budaya asing...

Pendapat di atas sebenarnya menegaskan bahwa kearifan lokal yang sudah ada saat ini. Selain dipahami juga diaplikasikan dalam wujud dan semangat yang 
sama akan tetapi pelaksanaan disesuaikan dengan kondisi dan keadaan yang berbeda.

Berdasarkan hasil observasi, penduduk masih berpegang teguh pada nilainilai budaya yang diwariskan secara turun temurun dari leluhurnya/karihunnya. Hal ini dibuktikan salah satunya mereka tidak berani membuat rumah yang tidak sesuai dengan aturan adat, yaitu rumah harus berbentuk panggung dan berukuran persegi panjang. Pernah ada yang membangun permanen (terbuat dari tembok), maka terjadi hal-hal yang sifatnya mistis pada keluarg tersebut, sehingga dibongkar kembali. Puing-puing rumah tersebut sekarang masih ada.

\section{b. Nilai-Nilai Kearifan Lokal yang Tercermin dalam Seluruh Kehidupan Masyarakat Adat Kampung Kuta}

Warsim (51), Warja, dan Sanmarno (66), menuturkan bahwa nilai-nilai karakter kearifan lokal masyarakat adat Kampung Kuta tercermin dalam (1) seni, yaitu seni suara, seni bangunan / arsitektur, dan seni sastra; (2) pepatah masyarakat adat Kampung Kuta pada dasarnya sama dengan kebanyakan pepatah orang Sunda; dan (3) pandangan hidup Masyarakat Kampung Kuta, yaitu pandangan hidup tentang manusia sebagai pribadi, hubungan manusia dengan masyarakat, hubungan manusia dengan Tuhan, manusia dalam mengejar kemajuan lahiriah dan kepuasan batiniah, dan pandangan hidup tentang alam.

Sejalan dengan pendapat narasumber di atas, Koentjaraningrat (2011: 7273) menjelaskan dengan menggunakan perspektif antropologi yang mengartikan kebudayaan sebagai seluruh sistem gagasan dan rasa, tindakan, serta karya yang dihasilkan manusia dalam kehidupan bermasyarakat, yang dijadikan miliknya dengan belajar. Koentjaraningrat (2011: 74-75) juga menjelaskan setidaknya ada empat unsur kebudayaan, yaitu wujud kebudayaan sebagai artifact atau bendabenda, sebagai sistem tingkah laku dn tindakan yang berpola, sebagai sistem gagasan, dan sebagai sistem gagasan yang ideologis.

Berdasarkan pendapat di atas, maka nilai-nilai kearifan lokal masyarakat adat Kampung Kuta yang tercermin dalam seni, pepatah, dan pandangan hidup, merupakan wujud dari kebudayaan yang eksis dan bisa ditelusuri keberadaannya sampai saat ini. 


\section{c. Nilai-Nilai Kearifan Lokal yang Ada pada Masyarakat Adat Kampung Kuta}

Warsim (51), Warja, dan Sanmarno (66), menuturkan bahwa nilai-nilai karakter yang ada pada masyarakat adat Kampung Kuta adalah sebagai berikut.

1) Tercermin dalam kesenian adalah karakter lembut, teratur, efisiensi, dan disiplin.

2) Tercermin dalam pepatah sunda, karakter saling menyayangi, saling menjaga, dan saling mengajari.

3) Tercermin dalam pandangan hidup Masyarakat Kampung Kuta, adalah meliputi bagian-bagian berikut:

a) Pandangan hidup tentang manusia sebagai pribadi, yaitu karakter ikhlas, taat/patuh, visioner (berfikir jauh ke depan), bertanggung jawab, pengabdian, dan setia.

b) Pandangan hidup tentang hubungan manusia dengan masyarakat yaitu karakter ikhlas, simpati, dan empati, rasa kasih sayang, toleran/bertengang rasa.

c) Pandangan hidup tentang hubungan manusia dengan Tuhan, yaitu karater patuh/taat, ikhlas, rela berkorban, pengabdian, iman dan taqwa.

d) Pandangan hidup tentang manusia dalam mengejar kemajuan lahiriah dan kepuasan batiniah, yaitu karakter Taqwa, sederhana, dan rendah hati.

e) Pandangan hidup tentang alam, yaitu krakter menghargai kesehatan, bijaksana, berfikir konstruktif, dan bertanggung jawab.

Nilai-nilai karakter tersebut di atas sebenarnya sesuai dengan pemaknaan kata "sunda" itu sendiri. Mengingat masyarakat Kampung Kuta merupakan bagian dari suku Sunda. Seperti yang dijelaskan Suryalaga (2009: 73-92), sebagian pemaknaan kata Sunda dapat diuraikan sebagai berikut.

1) Sunda, akar katanya adalah sund (seasal dengan kata sun dalam Bahasa Inggris yang berarti matahari); mengandung arti bercahaya, terang benderang. Mentafakuri arti kata Sunda di atas bisa dimaknai ibarat sinar matahari yang memberi penerangan di dunia dan menjadi sumber kehidupan 
bagi makhluk yang lain. Jadi bukanlah Sunda bila dirinya sendiri dalam keadaan gelap gulita. Lahir batinnya selalu suram tidak bercahaya. Jangankan memberi pelita penerang bagi orang lain atau memberi kehidupan bagi sesama makhluk, dirinya sendiri pun hidup dalam kegelapan. Sungguh sangat mengenaskan, hidup tanpa arah tujuan. Sunda yang bertabiat seperti ini mungkin hanya layak disebut sebagai Sunda samagaha (Sunda yang mengalami gerhana).

2) Sunda, berasal dari kata cuddha, berarti putih. Kata putih berkonotasi suci, bersih, ikhlas hati. Dalam idiomatik bahasa Sunda dikatakan clik putih clak herang artinya pikiran serta hati yang suci bersih. Lemah putih siniger tengah yaitu cara berpikir yang seimbang. Jadi bukanlah Sunda bila pikirannya penuh dengan tipu daya, serakah dan selalu berprasangka buruk terhadap orang lain, ingin menguasai orang lain.

3) Sunda, nama sebuah gunung pada zaman silam yang terletak di sebelah utara kota Bandung sekarang. Gunung Sunda menjulang tinggi 1.854 meter. (Gonda, 1973). Gunung Sunda pernah meletus dengan dahsyat antara 300.000 tahun yang lampau, menyisakan dinding sebelah barat yaitu Gunung Burangrang dan dinding sebelah timur sekarang disebut Bukit Tunggul. Di atas kalderanya tumbuh gunung baru yaitu Gunung Tangkuban Parahu. Jadi bukanlah Sunda bila tidak paham keberadaan dirinya sebagai makhluk ciptaan Allah SWT, serta tidak mampu meningkatkan kualitas jati dirinya dari yang bersifat kebendaan dan kehewanan menjadi makhluk yang bersifat kemanusiaan yang Ilahiah.

4) Sunda, artinya waspada. Waspada adalah sikap manusia yang selalu hati-hati penuh perhitungan, mampu memprediksi apa yang akan terjadi. Di masyarakat Sunda dikenal idiomatik: nasititi tah ati-ati, pinuh ku duduga prayoga, asak jeujeuhan matang timbangan, gede wiwaha, ka hareup ngala sajeujeuh, ka tukang ngala salengkah, dibeuweung diutahkeun, dipikir dibulak-balik, henteu kejot borosot sarigig jeung ati-ati sarengkak reujeung waspada (seluruh peribahasa ini mengandung arti harus tertib, hati-hati, waspada dan arif bijaksana). Jadi tidaklah dikatakan Sunda, bila bertindak asal asalan, tidak tertib, tidak mampu memprediksi apa yang akan terjadi. Bukanlah Sunda, bila 
masih mempunyai pandangan hidup "kumaha engke" (bagaimana nanti saja yang seharusnya mampu untuk memprediksi "engke kumaha" (nanti akan bagaimana jadinya).

5) Sunda, artinya angka 2 (dua) yang biasa digunakan dalam perhitungan candrasangkala/suryasangkala (perhitungan tahun berdasarkan bulan dan matahari, dengan menggunakan kata-kata yang dianggap mempunyai nilai angka tertentu). Angka 2 (dua) mengandung makna keadaan yang berlawanan seperti: papas : dingin, senang : susah, serakah : dermawan, dan sebagainya. Jadi tidaklah dikatakan Sunda apabila tidak mampu menggeluti kehidupan yang memang sering berlawanan tetapi saling melengkapi. Tidak mengetahui mana kewajiban dan hak dirinya. Kagalauan ini makin terasa manakala HAM (Hak Azasi Manusia) terlanjur sangat mendominasi KAM (Kewajiban Azasi Manusia sebagai homo socius).

Berdasarkan pada pengertian kata sunda di atas, maka pada hakikatnya adat dan tradisi budaya di masyarakat Kampung Kuta tidak terlepas dari nilai-nilai kearifan lokal sunda secara umum.

2. Pranata Sosial yang Membelajarkan Nilai-nilai Karakter Kepada Masyarakat

\section{a. Pranata Sosial yang Membelajarkan Nilai-Nilai Karakter pada Masyarakat Adat Kampung Kuta}

Warsim (51) dan Sanmarno (66), menuturkan bahwa pranata sosial yang membelajarkan nilai-nilai karakter pada masyarakat adat Kampung Kuta adalah melalui pranata pendidikan, pranata ekonomi, pranata keluarga, pranata politik, dan pranata agama.

Pranata sosial yang ada di masyarakat adat Kampung Kuta sampai saat ini masih terjaga. Oleh karena itu transformasi atau sistem pewarisan nilai-nilai kearifan lokal kepada generasi selanjutnya tidak terlalu menemui banyak kendala, hal ini dikarenakan berdasarkan hasil observasi, masyarakat Kampung Kuta sedikit mempunyai keturunan. Artinya angka kelahiran di daerah tersebut terbilang sedikit. Oleh karena itu jangan heran apabila kesana jarang menemui anak kecil. Saat peneliti melakukan observasi, disana hanya ada satu anak yang sedang bermain. 


\section{b. Teknik Pembelajaran Nilai-Nilai Kearifan Lokal pada Masyarakat Adat Kampung Kuta}

Warsim (51) dan Sanmarno (66), menuturkan bahwa teknik pembelajaran/ pewarisan nilai-nilai kearifan lokal pada masyarakat adat Kampung Kuta, dilakukan dengan cara:

1) Melalui pranata pendidikan, yaitu dengan menyekolahkan anak pada sekolahsekolah yang ada di daerah sekitar Kampung Kuta, dengan harapan mereka mempunyai wawasan yang luas, sehingga secara tidak langsung dapat memahami betapa pentingnya adat istiadat untuk dijaga dan dilestarikan

2) Melalui pranata ekonomi dapat dilihat dari mata pencaharian masyarakat Kampung Kuta yang sebagian besar adalah petani, yaitu petani padi dan gula aren. Dalam hal ini pembelajaran nilai-nilai karakter kearifan lokal/adat istiadat lebih kepada bagaimana mereka bersyukur dan berterima kasih pada Tuhan dan Alam dengan mengadakan upacara-upacara adat

3) Melalui pranata keluarga, masyarakat Kampung Kuta pada umumnya memberikan wawasan tentang nilai-nilai kearifan lokal melalui tradisi lisan. Dan yang paling berpengaruh adalah tradisi lisan dan contoh secara langsung di lingkungan keluarga dan masyarakat. Bagaimana anak masyarakat adat Kampung Kuta diberitahukan secara lisan tentang jati dirinya.

4) Paranata politik, pembelajaran secara langsung dalam paranata ini tidak ada, akan tetapi lebih kepada pembelajaran secara tidak langsung, yaitu dengan contoh. contoh yang dimaksud adalah misalnya dalam pemilihan kuncen dan ketua adat. pemilihan kuncen pada masyarakat adat Kampung Kuta tidak sembarangan. Dia harus keturunan langsung leluhur dari Cirebon yang dulu pertama kali menetap di Kampung Kuta. Sedangkan untuk pemilihan ketua adat, selain bersifat demokratis juga yang paling penting adalah harus adanya ilham/ilafat/wangsit dari para leluhur kepada tokoh/sesepuh masyarakat adat.

5) Melalui paranata agama, masyarakat adat Kampung Kuta merupakan manusia yang taat pada aturan yang telah digariskan oleh Tuhan dan leluhur. Oleh karena dalam paranata ini biasanya dibelajarkan secara tidak langsung melalui upacara-upacara adat. 
Bedasarkan pada beberapa pranata tersebut di atas, teknik pewarisannya pada dasarnya sebagian besar melalui tradisi lisan dan contoh secara langsung melalui upacara-upacara adat.

Pola pewarisan pada berbagai masyarakat adat yang penulis jumpai selain di Kampung Kuta, seperti misalnya di Baduy Dalam (Banten), Kampung Naga (Kabupaten Tasikmalaya), Kampung Dukuh (Kabupaten Garut), Kampung Mahmud (Kabupaten Garut), Desa Penglipuran (Bali), sebagian besar menggunakan tradisi lisan dan contoh melalui upacara-upacara adat.

Tradisi lisan ini merupakan proses pewarisan secara lisan dari orang yang lebih tua/sepuh kepada orang yang lebih muda sebagai pewarisnya kelak. Kegiatan tradisi lisan ini ada yang sifatnya berkelompok dan ada juga individual. Mereka menuturkan sama dengan apa yang mereka dapatkan dari penutur terdahulu yaitu leluhur/karuhun. Kalaupun ada modifikasi, itu tidak melenceng dari koridor/papagon yang sudah ditetapkan sejak sekian lamanya.

Selain itu, dalam masyarkat adat sarat dengan upacara-upacara adatnya. Hal ini sebenarnya menjadi media yang sangat efektif dalam mewariskan nilainilai kearifan lokalnya. Oleh karena penerusnya dapat melihat secara langsung apa yang akan ia lakukan nanti setelah dewasa.

3. Faktor-Faktor yang Menjadi Penguat Bertahannya Nilai-Nilai Kearifan Lokal pada Masyarakat Adat Kampung Kuta di Era Globalisasi dan Modernisasi

a. Faktor-Faktor Internal yang Menjadi Penguat Bertahannya Nilai-Nilai Kearifan Lokal pada Masyarakat Adat Kampung Kuta di Era Globalisasi Dan Modernisasi

Warsim (51) dan Sanmarno (66), menuturkan bahwa faktor internal yang menjadi penguat bertahannya nilai-nilai kearifan lokal pada masyarakat adat Kampung Kuta di era globalisasi dan modernisasi adalah dengan masih dipegang teguhnya istilah pamali. Pamali adalah satu kata yang menyebutkan berbagai arti tergantung pada situasi dan kondisi pada saat itu. Pamali biasanya berisi pantangan dan keharusan. Apabila kata pamali sudah terucap, maka tidak boleh ada siapapun termasuk masyarakat dari luar Kampung Kuta melanggarnya dan 
harus mentaatinya. Jikalau dilanggar atau tidak dilaksanakan, maka akan ada sangsi yang bersifat mistis.

Hal ini sejalan dengan pendapatnya Mulkan (2008) bahwa pamali adalah sebuah larangan untuk melakukan atau mengucapkan sesuatu yang berakibat buruk bagi diri dan lingkungannya. Jika dilanggar biasanya berhubungan dengan rejeki, jodoh, keturunan dan keselamatan. Pamali, biasanya berhubungan dengan sebuah kata lainnya yaitu mitos yang dianggap sebagian orang sebagai cerita yang tidak dapat dipertanggungjawabkan kebenarannya berdasarkan rasio dan logika manusia karena merupakan kumpulan cerita atau hal-hal yang dipercayai secara turun-temurun oleh suatu kelompok masyarakat tertentu. Maka mitos dianggap memiliki hubungan tertentu dengan kehidupan manusia di masa sebelumnya. Banyak orang tua yang sampai sekarang masih memegang teguh kepercayaan mereka tentang kebenaran sebuah mitos.

Berdasarkan pada pendapat di atas, istilah pamali sangat kuat pengaruhnya pada masyrakat adat yang berada di daerah Sunda. Kuatnya istilah ini, maka tidak ada seorang pun yang berani melanggar. Apabila ada yang melanggar maka akan ada sanksi yang menyertainya. Sanksi tersebut tentunya bersifat adat pula, yakni biasanya bersiafat religio-magis.

Sifat religio-magis berarti tentang kepercayaan terhadap hal-hal yang gaib, mistis, dan sulit diungkat secara rasio atau faktual. Oleh karena itu maka kepercayaannya berupa keyakinan yang membuat mereka patuh untuk tidak melanggar aturan-aturan adat.

Sungguh dahsayatnya kata pamali, sehingga sampai saat ini di daerah Sunda masih terdapat banyak masyarakat adat yang masih eksis dalam hiruk pikuknya budaya asing yang masuk ke Indonesia.

\section{b. Faktor-Faktor Eksternal yang Menjadi Penguat Bertahannya Nilai-Nilai Kearifan Lokal pada Masyarakat Adat Kampung Kuta di Era Globalisasi dan Modernisasi}

Warsim (51) dan Sanmarno (66), menuturkan bahwa faktor-faktor eksternal yang menjadi penguat bertahannya nilai-nilai kearifan lokal pada masyarakat adat Kampung Kuta di era globalisasi dan modernisasi adalah sebagai berikut: 
1) Adanya sikap toleran/tenggang rasa masyarakat yang ada di sekitar Kampung Kuta, sehingga hal ini membuat warga masyarakat Kampung Kuta merasa nyaman untuk hidup bermasyarakat meskipun ada perbedaan dari sisi adat istiadat.

2) Diterapkannya aturan oleh pemerintah Kabupaten Ciamis bahwa wilayah Kampung Kuta dijadikan sebagai wilayah adat dan pariwisata. Sehingga secara langsung dan tidak langsung warga masyarakat Kampung Kuta akan merasa untuk terus mempertahankan nilai-nilai kearifan lokalnya.

Berdasarkan pendapat di atas, dukungan pemangku kebijakan sangat penting. Oleh karena masyarakat adat yang ada saat ini sebagai warga negara yang baik dalam menjalani kehidupannya mau tidak mau harus sesuai dengan peraturan yang ada.

Hasil observasi yang peneliti lakukan menemukan hal-hal yang masih harus dibangun dalam upaya penyelenggaraan desa adat dan pariwisata, salah satunya adalah transportasi. Jarak yang jauh dari pusat kota menjadikan harus dibarengi dengan jalan yang bagus dan lebar, juga kendaraan umum yang bisa menjangkaunya. Sehingga memudahkan para wisatawan atau orang yang akan berkunjung kesana.

Perihal masyarakat adat, di Indonesia sebenarnya telah jelas peraturannya. Seperti yang termaktub dalam UUDNRI 1945 pasal 18 B (2), yaitu Negara mengakui dan menghormati kesatuan-kesatuan masyarakat hukum adat beserta hak-hak tradisionalnya sepanjang masih hidup dan sesuai dengan perkembangan masyarakat dan prinsip Negara Kesatuan Republik Indonesia, yang diatur dalam undang-undang.

\section{KESIMPULAN}

Berdasarkan hasil penelitian dan pembahasan, maka dapat disimpulkan bahwa:

1. Masyarakat Kampung Kuta berpersepsi bahwa kearifan lokal merupakan warisan budaya bangsa (amanat leluhur/karuhun), yang wajib untuk dijaga dan dilestarikan sebagai wahana pembentukan identitas dan jati diri. 
2. Nilai-nilai karakter kearifan lokal masyarakat adat Kampung Kuta tercermin dalam bidang seni, pepatah dan pandangan hidup Masyarakat Kampung Kuta (pandangan hidup tentang manusia sebagai pribadi, pandangan hidup tentang hubungan manusia dengan masyarakat, pandangan hidup tentang hubungan manusia dengan Tuhan, pandangan hidup tentang manusia dalam mengejar kemajuan lahiriah dan kepuasan batiniah, dan pandangan hidup tentang alam.

3. Nilai-nilai karakter yang ada pada masyarakat adat Kampung Kuta adalah sebagai berikut.

a. Tercermin dalam kesenian adalah karakter lembut, teratur, efisiensi, dan disiplin.

b. Tercermin dalam pepatah sunda, karakter saling menyayangi, saling menjaga, dan saling mengajari.

c. Tercermin dalam pandangan hidup Masyarakat Kampung Kuta, adalah meliputi bagian-bagian berikut:

1) Pandangan hidup tentang manusia sebagai pribadi, yaitu karakter ikhlas, taat/patuh, visioner (berfikir jauh ke depan), bertanggung jawab, pengabdian, dan setia.

2) Pandangan hidup tentang hubungan manusia dengan masyarakat yaitu karakter ikhlas, simpati, dan empati, rasa kasih sayang, toleran/bertengang rasa.

3) Pandangan hidup tentang hubungan manusia dengan Tuhan, yaitu karater patuh/taat, ikhlas, rela berkorban, pengabdian, iman dan taqwa.

4) Pandangan hidup tentang manusia dalam mengejar kemajuan lahiriah dan kepuasan batiniah, yaitu karakter Taqwa, sederhana, dan rendah hati.

5) Pandangan hidup tentang alam, yaitu krakter menghargai kesehatan, bijaksana, berfikir konstruktif, dan bertanggung jawab.

4. Pranata sosial yang membelajarkan nilai-nilai karakter pada masyarakat adat Kampung Kuta adalah melalui pranata pendidikan, ekonomi, keluarga, politik, dan agama. 
5. Teknik pewarisan nilai-nilai kearifan lokal pada masyarakat adat Kampung Kuta pada dasarnya dengan menggunakan tradisi lisan dan contoh secara langsung melalui upacara-upacara adat.

6. Faktor-faktor internal yang menjadi penguat bertahannya nilai-nilai kearifan lokal pada masyarakat adat Kampung Kuta adalah dengan masih dipegang teguhnya istilah pamali.

7. Faktor-faktor eksternal yang menjadi penguat bertahannya nilai-nilai kearifan lokal pada masyarakat adat Kampung Kuta adalah adanya sikap toleran/tenggang rasa masyarakat yang ada di sekitar Kampung Kuta dan dengan diterapkannya aturan oleh pemerintah Kabupaten Ciamis bahwa wilayah Kampung Kuta dijadikan sebagai wilayah adat dan pariwisata.

\section{DAFTAR PUSTAKA}

Alwasilah, A.C. 2006. Pokoknya Sunda, Interpretasi Untuk Aksi. Bandung: Kiblat buku Utama.

Aryani. IK, dan Markum. S. 2010. Pendidikan Kewarganegaraan Berbasis Nilai. Bogor. Ghalia Indonesia.

Koentjaraningrat. 2011. Pengantar Antropologi I. Jakarta: Rineka Cipta.

Miles, M. B., \& Huberman, A. M. (1992). Analisis Data Kualitatif: Buku Sumber tentang Metode-metode Baru. (T. R. Rohidi, Trans.) Jakarta: UI Press.

Mulkan, D. 2008. Pamali, Tradisi Budaya Lisan Leluhur Sunda. Tersedia: http://kabarindonesia.com/berita.php?pil=20\&dn=20080907190015. Diakses pada tanggal 20 September 2016.

Nasution, S. 2003. Metode Penelitian Naturalistik Kualitatif. Bandung: Tarsito.

Nazir, M. 2003. Metode Penelitian. Bogor: Ghalia Indonesia.

Pusat Kurikulum. 2010. Pengembangan Pendidikan Budaya dan Karakter Bangsa. Jakarta: Badan Penelitian dan Pengembangan Pusat Kurikulum Kementerian Pendidikan Nasional.

Sugiyono. 2007. Metode Penelitian Kuantitatif Kualitatif dan $R \& B$. Bandung: Alfabeta.

Sukadi. 2011. "Pendidikan Karakter Bangsa Berideologi Pancasila", dalam Budimansyah, D dan Komalasari, K (ed). Pendidikan Karakter: Nilai Inti Bagi Upaya Pembinaan Kepribadian Bangsa. Bandung: Widya Aksara Press.

Suryalaga. H. 2009. Kasundaan Rawayan Jati. Bandung: Yayasan Nur Hidayah.

Undang-Undang Dasar NRI Tahun 1945 
Jurnal Civics Volume. 13 No. 1 Tahun 2016

Yayasan Kebudayaan Rancage 2001. Laporan Konferensi Internasional Budaya sunda I 22-25 Agustus 2001. Bandung. 